\title{
SCREENING OF DIFFERENT TOMATO VARIETIES IN SALINE AREAS OF BANGLADESH
}

\author{
M.A. Siddiky1,2, P.K. Sardar' ${ }^{3}$ M.M. Hossain ${ }^{3}$, M.S. Khan ${ }^{4}$ and M. Khabir Uddin ${ }^{*}$ \\ Received 11 December 2011, Revised 13 February 2012, Accepted 15 June 2012, Published online 30 June 2012
}

\begin{abstract}
A field study was conducted to screen out a number of Bangladeshi Tomato (Lycopersicon esculentum L.) varieties for salinity tolerance. Three levels of salinity were $2.0-4.0 \mathrm{dS} \mathrm{m}^{-1}$, 4.1-8.0 dS m$~^{-1}$ and 8.1-12.0 dS m${ }^{-1}$. Significant varietal and or salinity treatment effects were registered on plant height, leaf area, plant growth, yield, dry matter plant ${ }^{-1}, \mathrm{Na}^{+}$and $\mathrm{Cl}^{-}$ accumulation in tomato tissues. Variety BARI Tomato 14, BARI Hybrid Tomato 5 and BARI Tomato 2 consistently showed superior biological activity at moderate salinity (4.1-8.0 dS m1), based on dry matter biomass production thus displaying relatively greater adaptation to salinity. Under saline condition, all plant parameters of tomato varieties were reduced compared to the control except number of fruits of BARI Tomato 14, BARI Hybrid Tomato 5 and BARI Tomato 2. Thus, BARI Tomato 14, BARI Hybrid Tomato 5 and BARI Tomato 2 can be regarded as a breeding material for development of new tomato varieties for tolerance to salinity in saline areas of Bangladesh.
\end{abstract}

Keywords: Tomato Varieties, Salinity and Screening

\footnotetext{
${ }^{1}$ Department of Environmental Sciences, Jahangirnagar University, Dhaka, Bangladesh. ${ }^{2}$ Horticulture Research Centre, BARI, Gazipur-1701, Bangladesh, ${ }^{3}$ On Farm Research Division, BARI, Khulna, Bangladesh and ${ }^{4}$ CSO (Ret'd), Soil Science Division, BARI, Gazipur-1701, Bangladesh.

*Corresponding author's email: khabir88@yahoo.com (M. Khabir Uddin)
}

Reviewed by Dr. Md. Mokter Hossain, Bangladesh Agricultural University, Mymensingh, Bangladesh.

\section{Introduction}

Salinity is a significant problem affecting agriculture worldwide, including Bangladesh, resulting in substantial losses in crop yield. In Bangladesh, coastal areas about 2.86 million ha covered by $30 \%$ of the total crop land of the country. Of this, nearly 1.056 million ha are affected by varying degrees of salinity (Karim et al., 1990). The severity of salinity of this area increases with the desiccation of the soil. It affects crops depending on degree of salinity at the critical stages of growth and reduces yield and in severe cases, total yield is lost. It has become imperative to explore the possibilities of increasing potential of these (saline) lands for increasing production of crops. Out of coastal cultivable saline area, about 328 (31\%), 274 (26\%) and $190(18 \%)$ thousand hectares of land are affected by very slight (2.0-4.0 dS m-1), slight (4.1$8.0 \mathrm{dS} \mathrm{m}^{-1}$ ) and moderate salinity (8.1-12.0 dS $\mathrm{m}^{-1}$ ), respectively are scope to successfully crop production (SRDI, 2010). Suitable cultivars are required to overcome the serious limitation posed by salt affected coastal areas. Tomato (Lycopersicon esculentum L.) is an important vegetable in Bangladesh. Extensive research is necessary to develop growing conditions in moderate salinity to produce good vegetative growth. The tomato plant is moderately sensitive to salinity (Peralta et al., 2005), although considerable differences between cultivars may be observed (Allen et al., 1998). Tomato can tolerate salinity up to $2.5-2.9 \mathrm{dS} \mathrm{m}^{-1}$ in the root zone without yield losses (Sonneveld and Van der Burg, 1991). The exact salinity level may vary depending on cultivar sensitivity (Caro et al., 1991) and environmental conditions (Karlberg et al., 2006). Therefore, the experiment was undertaken to evaluate the ability of ten varieties of tomato for growing under different saline conditions and screen them for salinity tolerance.

\section{Materials and Methods}

The field experiment was conducted in the farmer's field at three dispersed locations, Agricultural Research Station, BARI, Khulna, in a naturally salt affected soil to screen out the performance of salinity tolerant varieties of tomato. The properties of soil of the site are presented in Table 1a. The treatment consisted of three salinity levels 2.0-4.1, 4.1-8.0 and 8.1-12.0 
$\mathrm{dS} \mathrm{m}^{-1}$ as shown in Table 1a, Table $1 \mathrm{~b}$ and tomato varieties viz. BARI Tomato 2, BARI Tomato 3, BARI Tomato 4, BARI Tomato 8, BARI Tomato 9, BARI Tomato 11, BARI Tomato 14, BARI Hybrid Tomato 3, BARI Hybrid Tomato 4, and BARI Hybrid Tomato 5. The experiment was laid out in randomized complete block design with three replications. The unit plot size was $2 \mathrm{~m} \times 3 \mathrm{~m}$. Thirty day old seedlings were transplanted in 2030 November, 2010. Tomato production technology such as fertilizer and pest management, intercultural operations were done properly. Data were taken on different yield parameters like plant height, number and weight of fruits plant ${ }^{-1}$, root fresh weight, relative green mater value in youngest fully expanded leaves, leaf area plant-1, and biomass of root and shoot. $\mathrm{Na}^{+}$and $\mathrm{Cl}-$ concentration were also measured from dry mater of plant. Relative green mater value was measured with Minolta SPAD-502 chlorophyll meter. Statistical analysis of the data was performed and the means were compared at $5 \%$ probability level.

Table 1a. Properties of the naturally salt affected soil in the field experiment

\begin{tabular}{lcccc}
\hline Location & \multicolumn{4}{c}{ Soil depth $(0-15 \mathrm{~cm})$} \\
\cline { 2 - 5 } & $\mathrm{EC} \mathrm{dS} \mathrm{m}^{-1}$ & $\mathrm{pH}$ & $\mathrm{SAR}(\mathrm{mmol} \mathrm{L}-1)$ & Texture \\
\hline ARS farm, Khulna & $2.0-4.0$ & 7.3 & 2.1 & Clay loam \\
Khornia, Dumuria & $4.1-8.0$ & 7.79 & 11.64 & Clay loam \\
Panchpota, Dumuria & $8.1-12.0$ & 8.11 & 18.76 & Clay loam \\
\hline
\end{tabular}

ARS=Agricultural Research Station, EC=Electrical Conductivity, SAR=Sodium Absorption Ratio

Table $1 \mathrm{~b}$. Soil salinity class and area in coastal saline belt of Bangladesh

\begin{tabular}{lcc}
\hline Land classification & Salinity $\left(\mathrm{dS} \mathrm{m}^{-1}\right)$ & Saline area $\left(10^{3} \mathrm{ha}\right)$ \\
\hline Non saline with some very slightly saline & $\mathrm{S}_{1}(2.0-4.0)$ & 328 \\
Very slightly saline with some slightly saline & $\mathrm{S}_{2}(4.1-8.0)$ & 274 \\
Slightly saline with some moderately saline & $\mathrm{S}_{3}(8.1-12)$ & 189 \\
Strongly saline with some moderately saline & $\mathrm{S}_{4}(12.1-16.0)$ & 162 \\
Very strongly saline with some strongly saline & $\mathrm{S}_{5}(>16.0)$ & 102 \\
\hline
\end{tabular}

Source: SRDI, 2010

\section{Results and Discussion}

Plant growth was significantly affected by different varieties as well as salinity (Tables 2a \& $2 b)$. Treatment with lower salinity gave the higher values of most plant parameters as compared to the normal salinity. Plant height, leaf area, number of fruits, fruit weight, shoot and root dry matter weight were significantly different among the salinity levels across the tomato varieties (Tables $2 \mathrm{a} \& 2 \mathrm{~b}$ ). $\mathrm{Na}^{+}$and $\mathrm{Cl}^{-}$accumulation in the plant tissues was significantly $(\mathrm{P}<0.05)$ influenced by the tomato varieties and salinity levels (Table 3).

Table 2a. Response to salinity on the different yield parameter of tomato varieties

\begin{tabular}{|c|c|c|c|c|c|c|c|c|c|}
\hline \multirow[t]{3}{*}{ Variety } & \multicolumn{3}{|c|}{ Plant height (cm) } & \multicolumn{3}{|c|}{ Leaf area plant-1 $\left(\mathrm{cm}^{2}\right)$} & \multicolumn{3}{|c|}{$\begin{array}{c}\text { Relative green mater value } \\
(\%)\end{array}$} \\
\hline & \multicolumn{9}{|c|}{ Salinity EC $\left(\mathrm{dS} \mathrm{m}^{-1}\right)$} \\
\hline & $2.0-4.0$ & $4.1-8.0$ & $8.1-12.0$ & $2.0-4.0$ & $4.1-8.0$ & $8.1-12.0$ & $2.0-4.0$ & $4.1-8.0$ & $8.1-12.0$ \\
\hline BT2 & 82.5 & 78.8 & 69.5 & 445.1 & 488.6 & 385.5 & 36.2 & 38.0 & 40.2 \\
\hline BT3 & 91.4 & 85.6 & 70.6 & 472.5 & 445.3 & 371.6 & 35.1 & 36.6 & 36.4 \\
\hline BT4 & 92.3 & 87.4 & 76.6 & 488.4 & 419.6 & 382.7 & 34.8 & 35.9 & 36.2 \\
\hline BT8 & 87.6 & 78.5 & 66.8 & 445.6 & 410.3 & 316.1 & 35.4 & 36.8 & 39.1 \\
\hline BT9 & 88.7 & 79.6 & 59.6 & 450.8 & 417.2 & 321.5 & 35.6 & 37.3 & 39.2 \\
\hline BT11 & 115.3 & 106.4 & 90.2 & 455.1 & 421.3 & 313.6 & 35.2 & 37.5 & 38.9 \\
\hline BT14 & 119.7 & 115.3 & 111.6 & 510.2 & 695.5 & 450.4 & 36.6 & 38.8 & 40.6 \\
\hline ВНТЗ & 114.6 & 104.4 & 100.5 & 445.5 & 413.8 & 361.3 & 35.8 & 37.4 & 39.4 \\
\hline BHT4 & 102.7 & 98.8 & 71.2 & 469.3 & 452.4 & 372.7 & 36.1 & 37.8 & 39.7 \\
\hline BHT5 & 105.6 & 98.2 & 92.4 & 714.6 & 816.3 & 479.2 & 36.4 & 38.2 & 40.4 \\
\hline LSD & 17.21 & 11.53 & 9.75 & 125.85 & 112.67 & 98.48 & 2.59 & 2.75 & 5.05 \\
\hline
\end{tabular}

(0.05)

Note: BT2 = BARI Tomato 2, BT3 =BARI Tomato 3, BT4 = BARI Tomato 4. BT8 =BARI Tomato 8, BT9 =BARI Tomato 9, BT11 = BARI Tomato 11, BT14 = BARI Tomato 14, BHT3 = BARI Hybrid Tomato 3, BHT4 = BARI Hybrid Tomato 4 and BHT5 = BARI Hybrid Tomato 5.
The severe reduction in plant height demonstrated a consistent effect of high salinity in plant growth rate. BARI Tomato 14 was visually relatively stable and healthier even under the moderate salinity level (8.1-12.0 dS m1). Similarly, BARI Hybrid Tomato 5 and BARI Hybrid Tomato 3 and BARI Tomato 11 exhibited better performances as well as plant height among the ten tomato varieties (Table 2a). Adler and Wilcor (1987) found that salinity adversely affected the vegetative growth of tomato in respect of plant height and dry weight. superior with respect to plant height and it was 
Slight salinity $\left(4.1-8.0 \quad \mathrm{dS} \quad \mathrm{m}^{-1}\right)$ stimulated expansion of leaf surface in BARI Tomato 14, BARI Hybrid Tomato 5 and BARI Tomato 2 compared to the control while leaf area was in other tomato varieties posed in same salinity level. Salinity level 8.1-12.0 dS m-1 caused serious leaf surface reduction in all the varieties. Adams (1991) reported that comparisons of tomato in different salinity sources had led to the conclusion that the exposure of tomato to low and moderate salinity affected fruit growth mainly through osmotic effects rather than ion specific toxicity, provided that the basic nutrient supply is balanced and adequate.

On the other hand, green mater value did not differ among the varieties, but clearly demonstrated a steady adjustment in response to moderate salinity via elevated values with the increasing salinity across the ten varieties (Table 2a). Shani and Dudley (2001) reported that the yield loss was occurred due to reduced photosynthesis, high energy and carbohydrate expenses in osmoregulation and interference with cell functions under saline conditions.

Table $2 \mathrm{~b}$. Response to salinity on number of fruit, fruit weight and total dry matter plant ${ }^{-1}$ of ten tomato varieties

\begin{tabular}{|c|c|c|c|c|c|c|c|c|c|}
\hline \multirow[t]{3}{*}{ Variety } & \multicolumn{3}{|c|}{ Number of fruit plant ${ }^{-1}$} & \multicolumn{3}{|c|}{ Fruit weight (kg plant ${ }^{-1}$ ) } & \multicolumn{3}{|c|}{ Total dry matter (gplant ${ }^{-1}$ ) } \\
\hline & \multicolumn{9}{|c|}{ Salinity $\left(\mathrm{dSm}^{-1}\right)$} \\
\hline & $2.0-4.0$ & $4.1-8.0$ & $8.1-12.0$ & $2.0-4.0$ & $4.1-8.0$ & $8.1-12.0$ & $2.0-4.0$ & $4.1-8.0$ & $8.1-12.0$ \\
\hline BT2 & 21 & 24 & 20 & 1.70 & 1.71 & 1.60 & 16.45 & 12.83 & 7.80 \\
\hline BT3 & 20 & 18 & 16 & 1.45 & 1.22 & 1.16 & 11.94 & 9.97 & 6.00 \\
\hline BT4 & 19 & 16 & 14 & 1.40 & 1.10 & 1.02 & 11.84 & 9.76 & 5.94 \\
\hline BT8 & 25 & 19 & 18 & 1.58 & 1.34 & 1.22 & 13.37 & 11.11 & 6.47 \\
\hline ВТ9 & 26 & 22 & 19 & 1.61 & 1.38 & 1.27 & 14.48 & 11.49 & 6.85 \\
\hline BT11 & 34 & 29 & 23 & 1.50 & 1.26 & 1.11 & 12.70 & 10.52 & 6.23 \\
\hline BT14 & 27 & 29 & 26 & 1.93 & 2.01 & 1.80 & 19.64 & 15.79 & 9.91 \\
\hline ВНТ3 & 23 & 20 & 17 & 1.55 & 1.17 & 1.09 & 13.03 & 10.91 & 6.32 \\
\hline BHT4 & 25 & 21 & 20 & 1.62 & 1.43 & 1.25 & 15.85 & 11.86 & 7.15 \\
\hline BHT5 & 26 & 27 & 25 & 1.85 & 1.90 & 1.75 & 17.93 & 12.73 & 8.59 \\
\hline $\begin{array}{l}\text { LSD } \\
(0.05)\end{array}$ & 1.87 & 2.57 & 3.25 & 0.29 & 0.43 & 0.37 & 2.73 & 1.84 & 1.21 \\
\hline
\end{tabular}

In salinity level 4.1-8.0 $\mathrm{dS} \mathrm{m}^{-1} \mathrm{BARI}$ Tomato 14 , BARI Hybrid Tomato 5 and BARI Tomato 2 gave the highest values of fruit number and weight plant $^{-1}(29,27,24,2.01,1.90$ and 1.71, respectively). Whereas, variety BARI Tomato 4 gave the lowest values. There are inconsistencies in the literature regarding the contribution of fruit number to EC-induced reductions in tomato fruit yield. Eltez et al. (2002) reported that the number of fruits was unaffected by moderate salinity and that reduced yield was entirely due to smaller fruit. According to Olympios et al. (2003), the number of fruits plant ${ }^{-1}$ was restricted when the level of salinity in the root zone was $8 \mathrm{dS} \mathrm{m}^{-1}$ or higher. Comparing the response of different varieties to salinity, it could be clear that reduced in 8.1-12.0 dS m${ }^{-1}$ salinity. Moreover, the number of fruit and weight of variety BARI Tomato 14, BARI Hybrid Tomato 5 and BARI Tomato 2 was enhanced by salinity $\left(4.1-8.0 \mathrm{dS} \mathrm{m}^{-1}\right)$. This evidence could be a good sign for positive response of plants to salinity.

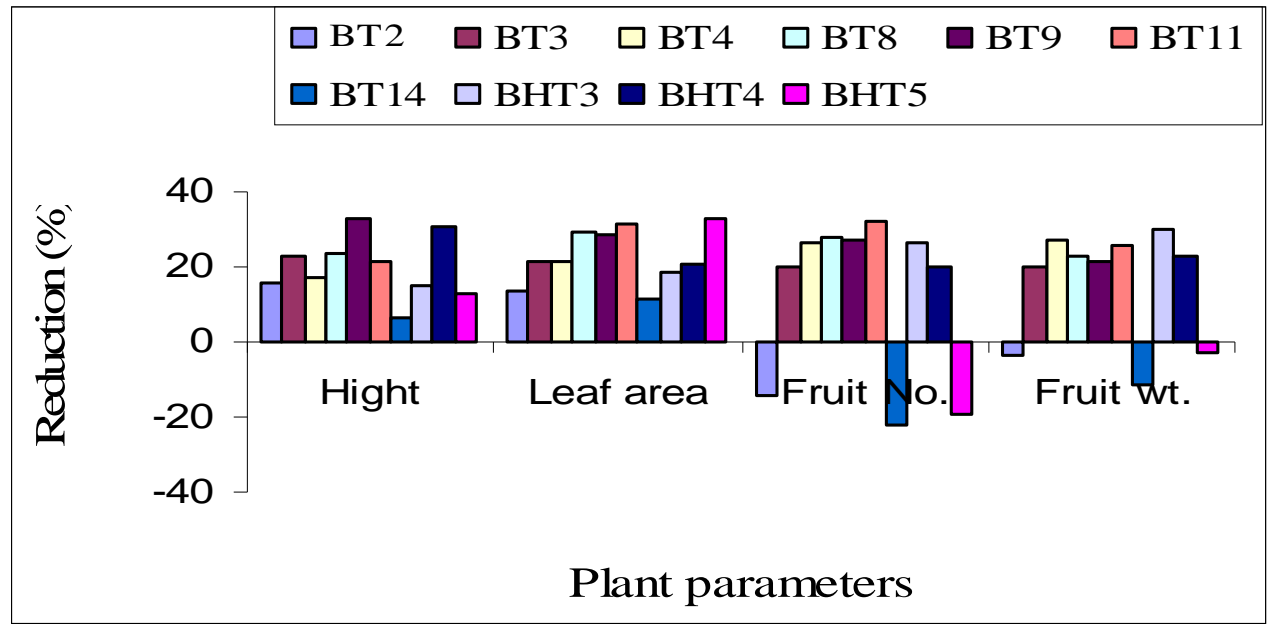

Fig. 1 Reduction in plant growth parameters due to salinity treatments 
Comparing the response of different varieties to salinity, it could be seen that all plant parameters of different varieties were reduced compared to control except number of fruits of some varieties such as BARI Tomato 14, BARI Hybrid Tomato 5 and BARI Tomato 2 (Fig. 1). Moreover, the fruit fresh weight for variety BARI Tomato 14, BARI Hybrid Tomato 5 and BARI Tomato 2 was enhanced by salinity. This evidence could be a good sign for positive response of plants to salinity.

Analysis of root and shoot dry matter in the experiment suggested a moderate susceptibility of the ten tomato varieties salinity under the field condition (Fig. 2). Salinity treatment stimulated the production (or maintenance) of more roots at a slight salinity level (4.1-8.0 $\left.\mathrm{dS} \mathrm{m}^{-1}\right)$, with BARI Tomato 14, BARI Hybrid Tomato 5 and BARI Tomato 2 showing the greatest response. Despite their moderate susceptibility to salinity, these varieties apparently exhibited very high genetis potential across the salinity level compared to the other seven varieties. Plaut et al. (2004) reported that the suppressive effect of moderate salinity on tomato fruit size seems to originate from a restriction of water transport into the fruit, which results in enhanced rates of dry matter accumulation.
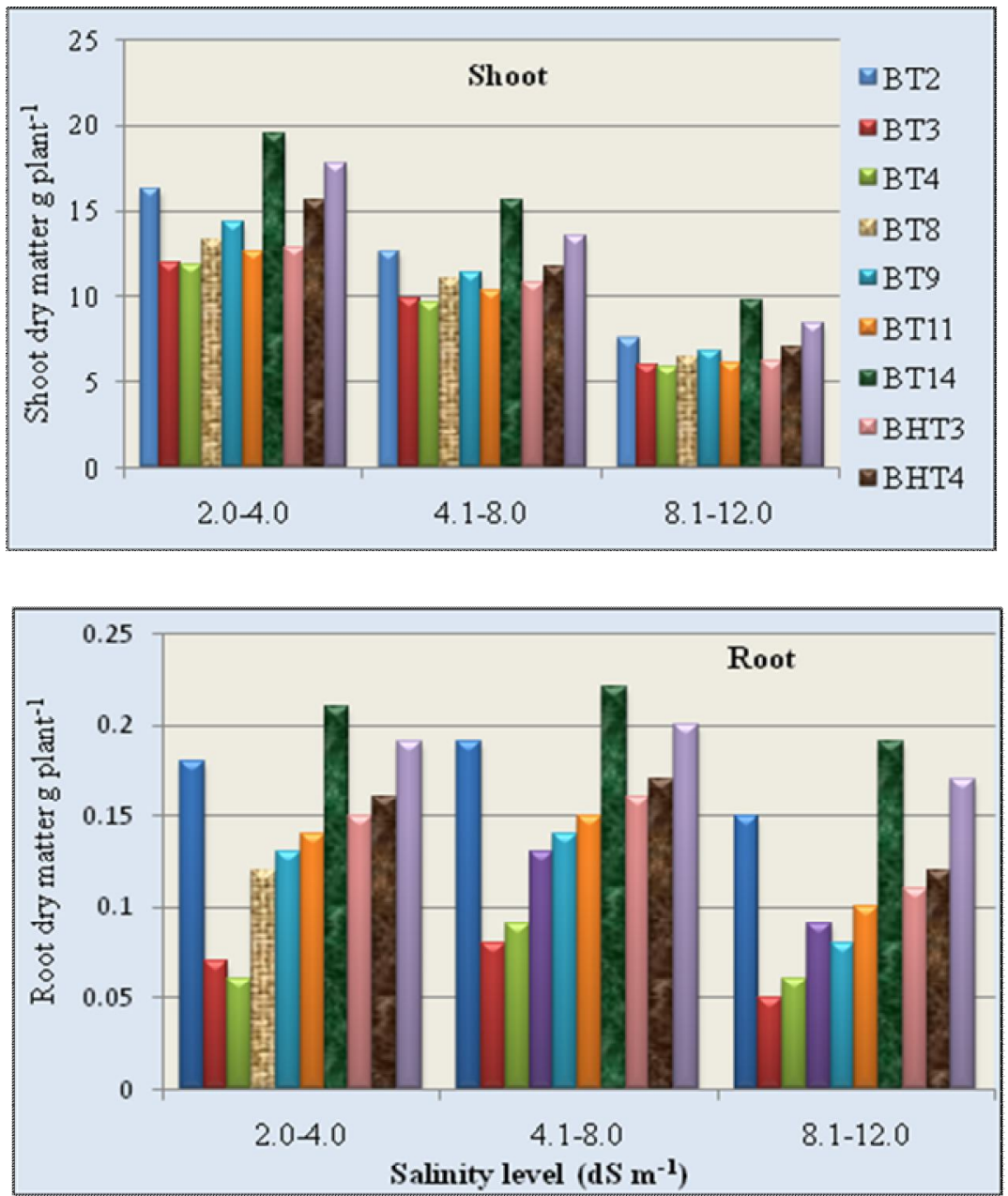

Fig. 2. Response of ten tomato varieties to different salinity based on shoot and root dry matter

Similarly, there was a considerable decrease in the root and shoot dry matter across the varieties at 8.1-12.0 ds m $\mathrm{m}^{-1}$ (Fig. 1). BARI Tomato 14, BARI Hybrid Tomato 5 and BARI Tomato 2 exhibited superior performance in respect of both root and shoot dry matter plant ${ }^{-1}$. On salinity treatment, dry matter production was adversely reduced in all the ten varieties, except for BARI Tomato 14, BARI Hybrid Tomato 5 and BARI Tomato 2. For instance, BARI Tomato 14, BARI Hybrid Tomato 5 and BARI Tomato 2 significantly produced more root dry matter at higher salinity treatment. The results indicated that the shoot and root dry weights decreased in saline condition, due to the moderate salinity (8.1-12.0 $\mathrm{dS} \mathrm{m}^{-1}$ ). Similar outcome were obtained earlier by Mohammad et al. (1998) in other tomato cultivars. 
Total dry matter yields, derived from the experiments, revealed that BARI Tomato 14, BARI Hybrid Tomato 5 and BARI Tomato 2 were produced more dry matter than the other varieties in different salinity level (Table 2b). The highest plant dry matter was recorded in BARI Tomato 14. BARI Tomato 14, BARI Hybrid Tomato 5 and BARI Tomato 2 were considered relatively tolerant to the moderate salinity (8.1-
$12.0 \mathrm{dS} \mathrm{m}^{-1}$ ), but BARI Tomato 4, BARI Tomato 3, BARI Tomato 11 and BARI Hybrid Tomato 3 were not significantly different on the basis of relative dry matter biomass. Based on this study, the four varieties are regarded as relatively weak to the moderate salinity (8.1-12.0 dS m-1). Heakal et al. (1990) reported that dry matter yield of plant shoots decreased with increasing salinity.

Table 3. Response to salinity on $\mathrm{Na}^{+}$and $\mathrm{Cl}$ - concentration in plant dry matter of tomato varieties

\begin{tabular}{l|ccc|ccc}
\hline \multirow{2}{*}{ Variety } & \multicolumn{5}{|c|}{$\mathrm{Na}^{+}$concentration plant-1 } & \multicolumn{3}{c}{$\mathrm{Cl}^{-}$concentration plant-1 } \\
\cline { 2 - 7 } & $2.0-4.0$ & $4.1-8.0$ & $8.1-12.0$ & $2.0-4.0$ & $4.1-8.0$ & $8.1-12.0$ \\
\hline BT2 & 1.0 & 32.5 & 41.9 & 14.5 & 65.8 & 85.8 \\
BT3 & 3.3 & 61.3 & 75.9 & 19.2 & 88.7 & 125.5 \\
BT4 & 3.7 & 63.2 & 72.1 & 19.0 & 90.3 & 121.4 \\
BT8 & 1.8 & 41.6 & 50.8 & 11.4 & 80.4 & 100.7 \\
BT9 & 1.6 & 40.3 & 48.4 & 18.5 & 75.2 & 98.4 \\
BT11 & 2.6 & 54.4 & 63.9 & 25.1 & 85.5 & 110.3 \\
BT14 & 0.5 & 21.7 & 30.2 & 14.2 & 50.1 & 70.2 \\
BHT3 & 2.4 & 50.2 & 60.7 & 12.6 & 84.6 & 105.5 \\
BHT4 & 2.2 & 45.8 & 58.6 & 9.2 & 70.4 & 93.6 \\
BHT5 & 1.1 & 28.6 & 39.4 & 13.8 & 62.3 & 80.4 \\
\hline LSD (0.05) & 1.25 & 15.68 & 17.63 & 6.23 & 9.88 & 12.83 \\
\hline
\end{tabular}

Mineral content analysis suggested that $\mathrm{Na}^{+}$and $\mathrm{Cl}$ - were accumulated in the plant for a majority of the tomato genotypes (Table 3). Both varietal and salinity effects, along with the interactions thereof, were detectable. Tomato variety BARI Tomato 14, BARI Hybrid Tomato 5 and BARI Tomato 2 demonstrated relatively low accumulation of the two ions $\left(\mathrm{Na}^{+}\right.$and $\mathrm{Cl}$ ) in a moderate salinity (8.1-12.0 $\left.\mathrm{dS} \mathrm{m}^{-1}\right)$ and low salinity (2.0-4.0 $\left.\mathrm{dS} \mathrm{m}^{-1}\right)$ treatment, Ghadiri el al. (2005) reported restricted water uptake by salinity due to the high osmotic potential in the soil and high concentrations of specific ions that may cause physiological disorders in the plant tissues and reduce yields. Salinity increases the accumulation of toxic ions such as $\mathrm{Na}^{+}$and $\mathrm{Cl}$ in different plant parts, tissues, cells and cell organelles. Accumulation of $\mathrm{Na}^{+}$and/ or $\mathrm{Cl}$ takes place in the chloroplasts of higher plants which affects growth rate, and is often associated with a decrease in photosynthetic electron transport activities in photosynthesis (Kirst, 1989).

\section{Conclusion}

Soil salinity is a major constraint to economic use of land for agriculture especially in the coastal regions of Bangladesh. The results of the present study showed that fruit yield of tomato were reduced by increasing salinity. Low salinity gave better results for most plant parameters and as salinity increased there was a reduction in plant growth and yield. Variety BARI Tomato 14, BARI Hybrid Tomato 5 and BARI Tomato 2 showed an optimistic response to saline agriculture by producing more yield under slight and moderate saline conditions. Hence, variety BARI Tomato 14, BARI Hybrid Tomato 5 and BARI Tomato 2 can survive and produce good yield in coastal fields of Bangladesh.

\section{References}

Adams, P. 1991. Effects of increasing the salinity of the nutrient solution with major nutrients or sodium chloride on the yield, quality and composition of tomatoes grown in rockwool. J. Hort. Sci., 66: 201-207.

Adler, P.R. and Wilcor, G.E. 1987. Salt stress, mechanical stress, or Chloromequat chloride effects on morphology and growth recovery of hydroponic tomato transplants. J . Am. Hort. Sci., 112: 22-25.

Allen, R.G., Pereira, L.S. Raes, D. and Smith. M. 1998. Crop evapotranspiration: Guidelines for computing crop water requirements. Irrigation \& Drainage. Paper 56. UN-FAO, Rome, Italy.

Caro, M., Cruz, V., Cuartero, J., Estañ, M.T. and Bolarin, M.C. 1991. Salinity tolerance of normal-fruited and cherry tomato cultivars. Plant and Soil., 136: 249- 255.

Eltez, R.Z., Tii-zel, Y., Gi.i, L.A., Tii-zel, J.H. and Duyar, H. 2002. Effects of different EC levels of nutrient solution on greenhouse tomato growing, Acta Hortic., 573: 443448.

Ghadiri, H., Dordipour, I., Bybordi, M. and Malakourti. M.J. 2005. Potential use of Caspian Sea for supplementary irrigation in North Iran. Agric. Water Manage., 79: 209224. 
Heakal, M.S., Modaihsh, A.S., Mashhady, A.S. and Metwally. A.I. 1990. Combined effects of leaching salinity and potassium content of water on growth and water use efficiency of wheat and barley. Plant and Soil, 125: 177184.

Karim, Z., Ibrahim, A.M., Iqbal, A. and Ahmed, M. 1990. Drought in Bangladesh Agriculture and Irrigation Schedules for Major Crops, Bangladesh Agricultural Research Council (BARC), Soils Public, No. 34. 11p.

Karlberg, L., Ben-Gal, A., Jansson, P-E. and Shani, U. 2006. Modeling transpiration and growth in salinity-stressed tomato under different climatic conditions. Ecological Modeling, 190: 15-40.

Kirst, G.O. 1989. Salinity tolerance of eu-karyotic marine algae: Annual Review Plant Physiology. Plant Molecular Biol., 40: 21-53.

Mohammad, M., Shibli, R., Ajouni, M. and Nimri, L. 1998. Tomato root and shoot responses to salt stress under different levels of phosphorus nutrition. J. Plant Nutr., 21: 1667-1680.

Olympios, C.M., Karapanos, I. C., Lionoudakis, K. and Apidianakis, I. 2003. The growth, yield and quality of greenhouse tomatoes in relation to salinity applied at different stages of plant growth. Acta Hortic., 609: 313-320.

Peralta, E., Knapp, S. and Spooner, O.M. 2005. New species of wild tomato (Solanum section Lycoperisicon: Solanaceae) fIom; Iorthem Pem. Systematic Bot., 30: 424-434.

Plaut, Z., Grava, A., Yehezke, I.C. and Matan, E. 2004. How do salinity and water stress affect transport of water, assimilates and ions to tomato fruits? Physiologia Plantarum, 122: 429-442.

Shani, U. and Dudley, L.M. 2001. Field studies of crop response to water and salt stress. Soil Sci. Soc. Am. J., 65:1522- 1528.

Sonneveld, C. and Van der Burg, A.M.M. 1991. Sodium chloride salinity in fruit vegetable crops in soilless culture. Netherlands J. Agri. Sci., 39: 115-122.

SRDI. 2010. Saline soils of Bangladesh. SRMAF project, Ministry of Agriculture, Govt. Peoples Repiublic of Bangladesh. 35p. 